\section{Legal Bases Of Foreign Policy Of The Islamic Republic Of Iran}

\section{Aramov Jamshid Abdurashidovich}

\author{
Student, Tashkent State University Of Oriental Studies, \\ Uzbekistan
}

\author{
G OPEN ACCESS \\ The American Journal of \\ Social Science And \\ Education Innovations \\ JULY 2020 \\ Page No.: 199-203 \\ Volume-II Issue-VII \\ PUBLISHED: 30 JULY 2020 \\ www.usajournalshub.com/inde \\ x.php/tajssei \\ Copyright: Original content \\ from this work may be used \\ under the terms of the \\ Creative Commons Attribution \\ 4.0 licence.
}

\title{
Abstract
}

The article analyzes the foreign policy of the Islamic Republic of Iran, its compliance with international law, and the main priorities of its foreign policy with the countries of the region.

Keywords: sovereign equality, international conventions, nuclear diplomacy, geopolitical factor, pragmatism.

\section{Introduction}

International relations are developing at a rapid pace. The interests of one state may not be consistent with another. However, in any case, foreign policy must respect and abide by the principles of international law. Iran's foreign policy, which is one of the biggest states in the region, is in compliance with international law and is about the main directions of its foreign policy in the Middle East.

\section{Methods}

The article explores Iran's foreign policy concepts and international law by using comparative-analytical, historical, systematic, and tracking methods.

\section{Materials}

The basic principles of modern jurisprudence are the interrelation with the main subjects and systems of law and the activity, legal aspects and goals of the activities of states and 
other entities related to other spheres and complacency ${ }^{1}$.

Today, we live in a rapidly changing world.The interests of the countries of the region are at odds with each other to follow the principles of international law. Each state should be guided by the norms of international law in defining its foreign policy priorities. The concluding document of the Organization for Security and Cooperation in Europe (1975) states that states have the right to become members of international organizations under sovereign equality, to participate or not to participate in bilateral and multilateral treaties and to remain neutral including neutrality.

\section{The Main Findings And Results}

When determining their foreign policy, states are guided by their constitutions and foreign policy concepts.

In addition, the Islamic Republic of Iran implements its foreign policy based on its concepts and principles. It is defined by the country's president and high religious leaders. It is well known that Iran became an Islamic state after the 1979 Islamic revolution. Religion oversees the conformity of major aspects of politics with high religious leaders. Iran also pursues its foreign policy according to UN resolutions, the Universal Declaration of Human Rights of 1948 and other conventions. there are also some limiting cases. In early 2010, the basic principles of Iranian foreign policy were outlined.The importance of this principle is determined by the Constitution of the Islamic Republic of Iran. Article 152 to Article 155 of the Constitution sets out the legal framework for foreign policy. These include:

Chapter X [Article 152 to 155]: Foreign Policy

Article 152: The foreign policy of the Islamic Republic of Iran is based upon the rejection of all forms of domination, both the exertion of it and submission to it, the preservation of the independence of the country in all respects and its territorial integrity, the defence of the rights of all Muslims, non-alignment with respect to the hegemonic superpowers, and the maintenance of mutually peaceful relations with all non-belligerent States.

Article 153: Any form of agreement resulting in foreign control over the natural resources, economy, army, or culture of the country, as well as other aspects of the national life, is forbidden.

Article 154: The Islamic Republic of Iran has as its ideal human felicity throughout human society, and considers the attainment of independence, freedom, and rule of justice and truth to be the right of all people of the world. Accordingly, while scrupulously refraining from all forms of interference in the internal affairs of other nations, it supports the just struggles of the Mustad'afun (oppressed) against the Mustakbirun (oppressors) in every corner of the globe.

Article 155: The government of the Islamic Republic of Iran may grant political asylum to those who seek it unless they are regarded as traitors and saboteurs according to the laws of Iran².

The principles of Iran's foreign policy at this time are as follows: 1 . Establishing peace relations with countries and supporting freedom situations; 2 . The pursuit of independence

\footnotetext{
${ }^{2}$ https://en.wikipedia.org/wiki/Constitution of the Islamic Republic of Iran\#Chapter X [Article 152 to 155]: Foreign Policy
} 
and sovereignty, the fight against chauvinism, the rejection of all forms of power; 3 . Exporting the Revolution and supporting the affected world population; 4 . The superiority of Islamic interests over national interests.

This is the most important priority for Iran's foreign policy in all areas. In Iran's foreign policy, the global dimension of Iran's foreign policy, based on the principle of "rejection of the rule and the tyranny of oppression: greatness," emerged during the presidency of Mahmoud Ahmadinejad. Islamic logic, based on the concept of foreign policy of the Islamic Republic of Iran, is based on the nature of modern Iranian foreign policy and its basic features are defined as the first principle and are implemented not only at global, but also regional and local levels.

The second principle that sets the right course for Iran's foreign policy is "the fight against oppression, for justice, and against arrogance." Fighting oppression is one of the traditional values of Iranians in pre-Islamic times, supplemented by the rule of rejection of colonization, the modern foreign policy of the Islamic Republic of Iran is included as a struggle against arrogance. The second principle in the field of foreign policy formed.

The third principle of Iran's foreign policy is, as a rule, the principle of "supporting the helpless and liberating movements." This is based on the Constitution of the Islamic Republic of Iran, the text of the Qur'an (Surat an-Nisa '75).

The fourth principle of Iranian foreign policy was the support and protection of Muslims. The third area of Iran's foreign policy has been formed on its basis, as Muslims around the world are the only ummah.

The fifth principle that set the right course for Iran's foreign policy was "Fight for Peace and Peace." Iranian foreign policy experts have focused on the fifth principle, as it is clear that the essence of Iran's peace-loving foreign policy is to protect its country and solve its foreign policy peacefully.

Principle Six enacts a policy of "non-interference and mutual respect in the internal affairs of countries" and "necessary and impartial for the prevention of war between states".

The seventh principle that sets out the relevant course of Iran's foreign policy is "adherence to treaties and international law. ${ }^{3 "}$

The seven basic principles of Iran's foreign policy that have been discussed below are the basis of the foreign policy concept

Such important geographical location of the country between the countries of the Middle East and Asia, as well as India, will not affect the foreign policy of Iran. , flexibility, mobility. Of course, each state pursues its own national interests in foreign policy. The Islamic Republic of Iran has a long history of foreign policy. The first foreign policy is aimed at protecting the national interests of the country, which is defined as a set of values.

This group of interests determines the Islamic Republic of Iran's place in the world. Among the factors that have had a profound impact on shaping key aspects of Iran's foreign policy in 2000 were the four groups of experts at the Center for History of Diplomacy and Diplomacy at the Iranian Foreign Ministry.

1.geographic 
2. historical and cultural.

3. Economic factor, ie oil factor

4. internationally

Ahmadinejad's "Iran's general guidelines" set the task of turning the country into an "Islamic Japan," meaning that the economy, science and technology will be at the forefront of the entire region by 2025. Relationships with American countries and the Shanghai Cooperation Organization have shown regional importance. With its ambitious development plans until 2025, Iran has the following objectives:

1. Preservation of the Islamic Republic.

2. Active foreign policy aimed at becoming one of the leading members of the club under the name of Iran's Multipolar World code 4 .

A careful reading of Iran's actions in the region will show how and why Iran has altered its goals to achieve its goals. Since the revolution, Iranian leaders have faced the challenge of balancing ideological and geopolitical (pragmatism) approaches to foreign policy. Gradually, the Iranian leadership has focused on the geopolitical factor in its foreign policy. Iran's regional policy has been pursued by ideology and geopolitics since the Islamic Revolution. Evidence of these two elements can be seen in the regional foreign policy of Iran over the years.

The state of the neighboring states of Iran is not very ambitious. According to Kayhan Barzegar, international relations expert, "There is sectarian conflict on the western wing of Iran (Iraq). Iran's eastern border has failed and fragile states (Afghanistan and Pakistan). Along the northern border of Iran, there are states whose political, social and economic developments are unstable and politically underdeveloped (Central Asia and the Caucasus). Such a hazardous environment can spark regional competition, instigate crises or military conflicts, and cause widespread involvement or direct intervention by major foreign powers. Much of Iran's political and economic investment is spent on countering these threats. " During the first decade of the revolution, Iran's regional foreign policy was largely ideologically determined. But then geopolitical factors began to prevail. Today, the ideology serves the interests and security of Iran. Given the numerous security challenges and Iran's potential, one can expect a pragmatic approach from the Iranian leadership in relations with the countries of the region that reflect the geopolitical reality.

The main directions of Iran's foreign policy in the Middle East include:

- To control the strait of Hormuz;

- strengthening its influence in Iraq and Afghanistan;

- Stability in Syria;

- further strengthening its position in the Arab (Sunni) world, participation in the Palestinian-Israeli conflict;

- Continuous development of the nuclear program 5 .

At the beginning of the 21st century, Iran's peaceful nuclear potential has also been recognized as one of Iran's most important interests. Recognition of Iranian leaders as leaders of the world's leading nations is a key condition that determines Iran's approach to developing its nuclear program. The emergence of the strategic course is a sign of the process of globalization and requires special study. The Iranian nuclear project, headed by 
President Ahmadinejad, represents the strategic agreement of the Iranian political elite. It produces 7,000 megawatts of nuclear power.

It is clear that all negotiations and all changes in Iran's foreign relations are under the control of the supreme leader. Ayatollah Ali Khamenei made it clear that the nuclear issue was not a presidential issue but a national issue before the election. Following last November's talks, the New York Times reported that Iran's acting foreign minister "often warned that the decision was in the hands of Supreme Leader Ayatollah Ali Khamenei ${ }^{6}$. "

\section{Conclusion}

To sum up, we can say that Iran's foreign policy is based on the above principles, that is, respecting the sovereignty of other countries is pursuing a peaceful foreign policy. Iran's nuclear presence can cause serious concern for the region's countries, particularly Saudi Arabia. This is contrary to US interests in the Middle East. The US will do everything possible to prevent Iran from having nuclear weapons.

\section{References}

[1]. Odilqoriyev.X.T. International public law. (Textbook) -T: 2005. - pp. 50-51

[2]. Dexgani-Firuzabadi D.S. Siyasat-e xaredji-ye djomxuri-ye eslami-ye Iran. - Tehran: Sazeman-e motale'e va tadvin-e ketab-e alum-e ensani-ye daneshgaxxa (Samt), 1388. [Dexgani-Firuzabadi S.D. Foreign policy of the Islamic Republic of Iran. Tegeran, 2009/2010.] (In Persian)

[3]. Saraev V. Yu. Foreign policy of the Islamic Republic of Iran in the system of international relations. (Final qualifying work) Ekaterinburg: 2018. - pp. 74-79

[4]. Kenneth Katzman Specialist in Middle Eastern Affairs .Iran's Foreign and Defense Policies. Congressional Research Service https://crsreports.congress.gov

[5]. Understanding Iranian Foreign Policy - The Case of Iranian Nuclear Program.

[6]. Emir Hadžikadunić, PhD Candidate, International University of Sarajevo, Bosnia

[7]. and Herzegovina; e-mail:ehadzikadunic@ius.edu.ba.

[8]. Understanding Iranian Foreign Policy - The Case of Iranian Nuclear Program.

[9]. Emir Hadžikadunić, PhD Candidate, International University of Sarajevo, Bosnia [10]. and Herzegovina; e-mail:ehadzikadunic@ius.edu.ba 